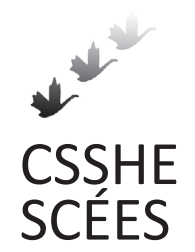

Canadian Journal of Higher Education Revue canadienne d'enseignement supérieur

Volume 45, No. 2, 2015, pages 193 - 213

\title{
The University Corporatization Shift: A Longitudinal Analysis of University Admission Handbooks, 1980 to 2010
}

\author{
Cliff Davidson \\ University of Western Ontario
}

\begin{abstract}
This paper explores university corporatization and its impact on university literature, examining the frequency and placement of content in the admissions handbooks (viewbooks) of six Ontario universities from 1980 to 2010, at five-year intervals. Government budget cuts implemented in the mid1990 s served as a point of interest in the timing of corporatization. Content analysis showed a decreased emphasis on academics and an increased emphasis on the university experience; academics moved toward the back of the viewbooks, and student experience and university-specific advantages moved toward the front. The timing of these changes, however, did not correlate, as expected, with government budget cuts of the mid-1990s.
\end{abstract}

\section{Résumé}

Cet article examine la privatisation des l'universités et ses effets répercussions sur la littérature publication universitaire. Sur des intervalles de 5 ans, les auteurs étudient Six universités de l>Ontario sont étudiées pour examiner la fréquence et le placement la disposition du contenu dans les de manuels d'admission à l>universitéde six universités ontariennes, publiés de 1980 à 2010, utilisant des intervalles de 5 ans. Les compressions budgétaires gouvernementales mises en œuvre par le gouvernement dans vers la moitié des années 1990 servent de point central pour l'analyse de la privatisation des universités. L'analyse de contenu est utilisée pour examiner le placement et la fréquence de contenu dans les manuels d aadmission. Les résultats indiquent une diminution de d'attention l'attention portée sur le contenu académique et une augmentation de l'emphase mise l'importance de sur l>expérience universitaire. C'est ainsi que le contenu académique a été déplacé vers la fin des manuels d'admission, tandis que les éléments de la vie étudiante, et une augmentation du contenu associé à l'expérience des étudiants et des avantages 
spécifiques propres de à chacune des universités étaient mis en évidence, au début de la publication. Toutefois, la période à laquelle Le moment de ces changements ont été apportés, cependant, ne correspond pas avec à celle celui des compressions coupes budgétaires gouvernementales mises en œuvre par le gouvernement dans le milieu vers la moitié des années 1990.

Education has been heavily scrutinized in recent years as it becomes increasingly corporatized and more about selling the student experience and less about educating democratic citizens (Giroux \& Searls Giroux, 2004). Research notes two causal factors leading to the corporatization of universities: a decline in public funds for higher educational institutions, and the inefficient use of funds that are allocated (Clark, Moran, Skolnik, \& Trick, 2009; Clark, Trick, \& Van Loon, 2011; Hacker \& Dreifus, 2010). Additionally, Klein (2000) and Tuchman (2011) have looked into the branding of the university, arguing that the many partnerships that arise in conjunction with research are another factor in the push towards corporatization. Although corporatization of universities-in this case, in Canada-is accepted as the prevailing trend (Slaughter \& Rhoades, 2009), the research in this paper explores whether it has impacted universities' recruitment and marketing strategies and, if so, how. Looking at university admissions handbooks (known as viewbooks) from six Ontario universities from roughly 1980 to 2010, the study seeks to answer two questions. First, have viewbooks changed over time in a manner that reflects a shift towards university corporatization? Second, if there is temporal change, is it gradual or sudden? Answers to these questions will shed a broader light on processes of corporatization at Ontario universities.

This research explores whether what is marketed by six Ontario universities has changed emphasis from academics to the university experience. I posited that academics would be less emphasized in university viewbooks, while the student experience and university-specific advantages would garner more attention. Such changes can be taken as indications of a more corporatized marketing push, as universities move towards selling the university experience they can provide, rather than the education students can receive.

\section{The Corporatization Shift}

One of the most talked about issues within higher education in Canada is how it has become more commodified and has been transformed into a consumable. Within the Ontario context, we see that although all universities have historically been publicly funded, reports from the early 1980 s documented the difficulty or impossibility of continuing to publicly fund the rapidly expanding higher education system (Clark et al., 2009; Commission on the Future Development of the Universities in Ontario, 1984; Ontario Ministry of Colleges and Universities, 1981). The Ontario government largely ignored these reports, and consequently, Ontario universities have suffered from funding deficits, leading them to find creative ways to secure more funding. A notable result is what researchers have called the commodification of education (Coates \& Morrison, 2011; Côté \& Allahar, 2011; Kaye, Bickel, \& Birtwistle, 2006).

Often the terms commodification, consumerism, and corporatization (and their variations) are clumped into the singular idea of 'selling education.' However, although the terms are related, important distinctions must be made. As Kaye, Bickel, and Birtwistle (2006) note, part of the problem in the distinction between commodification and consumerism 
stems from the fact that there has been a move that sees education "as something to be 'consumed' rather than as an activity in which to participate" (85). Consumerism-in the context of modern Western society-is defined as "the belief that individuals obtain gratification and social standing primarily through their purchase of commodities and consumption of tangible products"; the implication for education is that "students will want to see obvious, tangible benefits from their studies, whether in terms of an inherently valuable qualification, or as a route to a particular form of employment” (Kaye et al., 2006, p. 86).

Nonetheless, the idea of education as a commodity to be bought and sold has been around since before modern consumerist society's concept of commodified educationeducation has always been able to be bought and sold by those with money (Kaye et al., 2006). The new distinction is in the way that education is being consumed. Education that was purchased in the past was not subjected to questions about its efficiency and validity to the extent that it has been in modern consumerist society. Modern consumerist society has aligned education as a tangible product to be consumed, exchanged, and returned according to the will of the consumer-the student, and increasingly, their parents who help to pay for it (Apple, 2007; Kaye et al., 2006). This can be seen in the increasing litigation brought against universities for not providing the service or product that was purchased by the consumer (Kaye et al., 2006).

Similar to commodification of education is the corporatization of education. In his book, The Corporate Campus: Commercialization and the dangers to Canada's colleges and universities, Turk (2000) refers to commercialization as the term "most commonly used to designate the attempt to hitch universities and colleges to the private sector" (p. 4). The European Students' Union has noted that it is "the increasingly commercialised way in which higher education is being dealt with that is referred to as 'commodification' of education" (n.p.). Hence, the commercialization of education is intimately linked with its commodification. Westheimer (2010) added that universities are more and more modelled after corporations and structured to maximize profit, growth, and marketability. This understanding of corporatization is the main concern of the research leading to this paper. The fact that there is much literature showing a concern with the push to the corporatization of education (Coates \& Morrison, 2011; Côté \& Allahar, 2011; DavidsonHarden \& Majhanovich, 2004; Hacker \& Dreifus, 2010; Häyrinen-Alestalo \& Peltola, 2006; Newfield, 2008; Slaughter \& Rhodes, 2009; Tuchman, 2011) implies that a change has occurred. But what has changed and why?

Current literature lists a multitude of effects resulting from corporatization of the university, giving an idea of the changes that have occurred in the higher education system. Care must be taken here, though, because it is unclear whether some of these effects have actually contributed to, are a result of, or have run in parallel to the corporatization process. Corporatization has been associated with the following phenomena: student disengagement, massification, administrative overload, branding of the university, vocationalism, increases in tuition and related costs, a diminished role for academics in policy, the compromising of research, and a lack of agreement on the goal of university curricula (Clark et al., 2009; Coates \& Morrison, 2011; Côté \& Allahar, 2011; Davidson-Harden \& Majhanovich 2004; Hacker \& Dreifus, 2010; Häyrinen-Alestalo \& Peltola, 2006; Newfield, 2008; Slaughter \& Rhodes, 2009; Tuchman, 2011; Turk, 2000; Westheimer, 2010). The impacts of corporatization and commodification are known, but what brought about 
these changes in the university-what modifications pushed Ontario universities to further commodify their products, and, in turn, altered the consumption patterns of higher education? Lack of funding is the most commonly identified cause.

Looking at the lack of funding in the Ontario higher education context, the literature notes some factors that have contributed to university deficits (which, in turn, are contributing factors to the corporatization of education): massification and the resulting increase in administration, the increased costs of technological advances, and federal and provincial funding cuts. Massification-the explosive increase of student populations entering higher education and the deconstruction of education as an elite-only consumable-has contributed significantly to funding deficits. Research has shown that the associated per-student costs have increased to a level unsustainable by universities (Clark et al., 2009; Coates \& Morrison, 2011; Côté \& Allahar, 2011). In Ontario, massification of the university can be seen in three distinct cohorts: the baby boom generation (right after the Second World War); the 1986-1992 cohort, characterized by an increase in women's participation (along with more immigrant and rural students); and the double cohort that occurred in 2003 when Ontario Academic Credits (OACs) were dropped from the secondary school curriculum (Clark et al., 2009). In conjunction with these demographic and policy changes, funding adjustments also occurred. Funding was specifically allocated for the baby boom generation and the double cohort, because those structural changes were planned; however, increased funding allocations were implemented only haphazardly for the 1986-1992 cohort, as this burst of enrolments was unexpected (Clark et al., 2009). Massification can therefore be seen as contributing to budget pressures, which are among the contributing factors to the commodification of the university. Each of the three massive enrolment increases, occurring at different times, built upon the preceding level, so one cohort cannot be seen as contributing more than any other.

Interconnected with massification of the university are the compounded costs of facilitating the influx of students. More administrative positions were created, more facilities and classrooms were built, and there was an expansion of existing student services and a growth of new ones (Clark et al., 2009; Coates \& Morrison, 2011; Hacker \& Dreifus, 2010; Klein, 2000; Newfield, 2008; Tuchman, 2011). The discussion of administrative overhead is limited in this paper, as there is not a well-defined consensus as to what types and aspects of administrative overhead are a product of, rather than a contributor to, the commodification of education. Administrative overhead has an impact on the commodification of education, though to what extent is unknown.

Another cause of the funding shortfall is more and newer technologies. As technology advanced through the 1980 os and 1990s, more students expected it to be available for use in higher education-not only new technology, but the most cutting-edge technology. The problem is that most universities were not and are still not able to keep up with the pace of change (Côté \& Allahar, 2011; Taylor, 2010), even though the costs of technological advances are decreasing. Many universities have implemented an unwritten but broadly accepted and understood "bring your own device" (BYOD) policy; look around many lecture halls or classrooms, and you will see students' own laptops, tablets, and even smartphones being used for class purposes. The combined impact of the pace of change and the numbers of new students seems to be offset by the BYOD approach, as such, it is not yet clear how greatly university budgets will be affected by technological change. Research is still needed on this subject. (See Weinstock, 2010, for a discussion in an American high school context.) 
Perhaps the biggest contributor to the commodification of education that shows up in the literature is federal and provincial funding cuts. Frequently, studies focusing on Ontario post-secondary education cite provincial funding cuts as a key contributing factor in the commodification of education. In 1996, Ontario's government, led by Premier Mike Harris, cut the operating budgets of universities by $15 \%$, creating a funding deficit that was exacerbated by the increased costs stemming from the 1986-1992 expansion of enrolments (Clark et al., 2009; Davidson-Harden \& Majhanovich, 2004). Although these cuts are often identified as a key turning point in the increase of corporatization of the university, research by Clark and colleagues $(2009,2011)$ has pointed to the provincial government's subsequent rebuilding of the funding going to universities (almost to pre1996 levels), leading students and their parents to ask why tuition hikes have continued. With increasing tuition, questions of where and how the money is being spent arise. The answers are often connected to increases in administrative costs, infrastructure costs, and technology costs (Clark et al., 2009, 2011; Côté \& Allahar, 2011). Universities still claim financial instability and unsustainability even as their funding is slowly reinstated-universities are still pushing towards corporatization.

In the compounded problems of the massification of the university and attached administrative costs, the increased costs of technology, and the federal and provincial funding cuts, the multilayered causes of commodification are visible. Nevertheless, the key moments leading to corporatization of higher education in Ontario are not clear. If it is true, as Westheimer (2010) and Giroux and Searls Giroux (2004) have contended, that the more corporatized the higher education system becomes, the more we lose our democratic way of life, then it is imperative to identify when and how corporatization came about. Although some contributing factors are known, the timing of when the universities started to implement this rhetoric of corporatization must also be determined.

Many aspects of corporatization have been discussed in the literature including: corporate branding, corporate research partnerships, increased 'business-like' services, and private company sponsorship deals (Clark et al., 2009; Coates \& Morrison, 2011; Hacker \& Dreifus, 2010; Klein, 2000; Slaughter \& Rhodes, 2009; Tuchman, 2011). However, in this paper the concern is not what universities have done but, rather, how universities portray themselves through their promotional literature. For this reason, I examined universities' administrative and promotional documents and materials, specifically admissions handbooks presented to potential student-consumers.

\section{University Admissions Handbooks}

Admissions handbooks-often called viewbooks-are "glossy multi-page brochures that colleges and universities send to tens of thousands of prospective students each year[and] are an important medium by which institutions of higher learning entice students to matriculate" (Hartley \& Morphew, 2008, p. 671). Admissions handbooks were chosen for this study because of their applicability, availability, and persistence of use over time. Though some information about universities has been transferred to websites, three issues arise as to the extent of websites' impact on viewbooks. First, the World Wide Web has been publicly available only since 1993, and as such, much information was not available online until after that time. Second, Internet technologies and websites are in constant flux, making it difficult to discern when universities transferred or copied information to websites, and in what measure. Third, though there is a way to view archived versions of 
websites (the Internet Archive's Wayback Machine), only data posted since 1997 are available. Also, while the Internet has become ubiquitous in universities' recruitment strategies, there has also been an increase in direct mailing of viewbooks to prospective students (Breland, Maxey, Gernand, Cumming, \& Trapani, 2000). This indicates that though websites have become popular recruitment tools, they are but one of the many implements used to attract prospective students, with viewbooks still a main source of information.

Noting that the main purpose of a viewbook is to recruit students, it should come as no surprise that the internal messages have changed over time. As Hartley and Morphew (2008) stated, "Viewbooks are selling to prospective students in the same way that print ads, billboards, and television screens do" (p. 688). Several studies have examined viewbooks empirically with definitive results, lending to the applicability of viewbooks and content analysis as useful for research (Durgin, 1998; Hartley \& Morphew, 2008; Hite \& Yearwood, 2001; Saichaie, Hevel \& Morphew, 2012). In the past, what drove content was mostly promotion of the education that the university offered and not student enrolment. However, with increasing competition for students (and with higher enrolment levels, leading to increases in provincial funding with the 'bums on seats' method of funding), viewbooks have morphed over the years to address this need (Hite \& Yearwood, 2001). It is these messages that are explored in this paper through a content analysis, which has been shown to be an empirically sound method of examination for meaning and theme identification (Krippendorff, 2004).

\section{Previous Research}

Though viewbooks have been noted as an integral part of universities' recruitment strategies, little research has been done on them. The limited research that has been done has been under the purview of American colleges and universities only; no studies have been done from a Canadian point of view. Moreover, the research has been cursory in conceptualization and method. Hartley and Morphew (2008) empirically examined viewbooks' messages to potential students, noting that there was an overall utopian university experience being sold. Though their study examined viewbooks from a large number of institutions, the data were not longitudinal. Similarly, Hite and Yearwood's (2001) study focused on how the universities' messages were portrayed at one point in time. Their study was based on counts of pages and pictures and what those counts implied about each university's portrayal of itself. Confirming this, Kirp (2004) used pictures and text as indicators of a single university's change away from a generic viewbook towards more of a market tool with content that verged on deception (pp. 18-19; see Lucas, 1998, for a further discussion of the same university's viewbook). Though Kirp's study showed change over time, it focused on a single point of sudden change. One study that did examine viewbooks longitudinally is that of Saichaie, Hevel, and Morphew (2012). Their examination of 40 years of viewbooks from two different universities focused on what message was portrayed. It was found that the message had not changed over time, and that "popular conceptions suggesting that IHEs [Institutions of Higher Education] have dramatically changed the way they market their colleges and universities is [sic], in fact, not supported by the empirical evidence" (Saichaie et al., 2012, p. 31). The study suggests that the universities' messages about social mobility and credentialism recurred throughout the 40 years examined and did not alter over time. 
These studies, though they empirically contributed to the research, showed conflicting results. Hartley and Morphew's (2012) study and Kirp's (2004) research (as well as articles by Lucas, 1998, and Supiano, 2012) suggested that corporatization has occurred, changing over time, while Saichaie et al. (2008) said that over time viewbooks have stayed constant, continually promoting the same message. Also, some studies focused on what message is portrayed but not how it is portrayed, or did not look at the data longitudinally. It is with these points in mind that I undertook the present study on viewbooks. This research is important because it is the first of its kind with a focus on Ontario universities. Also, it combines methodologies from previous studies while implementing new measures not yet studied. Combining longitudinal analysis, a nuanced sample of six universities from three categories in Ontario, page counts, and an examination of the unstudied measure of content placement, this study seeks to create a thorough and robust set of data not yet seen in viewbook analysis.

\section{Collecting and Analyzing University Admissions Handbooks}

\section{Sample Selection and Data Collection}

In selecting universities for analysis, I used Canada's de facto guide to universities: Maclean's magazine. Maclean's divides Canadian universities into three groups: primarily undergraduate, comprehensive, and medical/doctoral (Maclean's, 2013). Six Ontario universities-two from each group-were selected for analysis. The choice of two universities per group allowed for an analysis of the differences-if any-among groups, as well as an overall analysis.

Two universities were randomly chosen per group, and the choices were then considered based on availability and access to information, and for status and length of time as a university. Some of these initial choices had to be replaced. Two hurdles in collecting the data were availability and consistency of viewbooks. Unfortunately, not all institutions had complete holdings, so it was not possible to analyze the same number or the same years of viewbooks from the six universities, though every effort was made to achieve consistency. All universities chosen are in Ontario and have been independent (non-affiliated) degree-granting university institutions since at least 1980. The universities chosen were: in the primarily undergraduate group, Trent University and Lakehead University (in place of Laurentian University due to lack of resources); in the comprehensive group, York University and University of Waterloo (in place of University of Guelph due to lack of resources); and in the medical/doctoral group, University of Western Ontario and University of Toronto.

Viewbooks were collected through various university departments: archives and libraries, communications, liaison, recruitment, admissions, and university websites. Data were captured through scans and digital photographs; digital copies of a few of the more recent viewbooks were obtained via email or university websites. One university sent printed viewbooks by mail. Using a method similar to that of Saichaie et al. (2012), I gathered viewbooks from 1980 to 2010 at roughly five-year intervals $(1980,1985,1990$, etc.). When a viewbook was unavailable, one close to the five-year interval was substituted-for example, 1998 instead of 2000.

The final collected data consisted of 35 viewbooks. Their dates and page lengths are shown in Table 1. 
Table 1.

Analyzed Viewbooks: Universities, Years, Page Lengths

\begin{tabular}{|c|c|c|}
\hline University & Year & Pages \\
\hline \multicolumn{3}{|c|}{ Primarily Undergraduate } \\
\hline \multirow[t]{8}{*}{ Trent } & 1979 & 22 \\
\hline & 1981 & 24 \\
\hline & 1986 & 30 \\
\hline & 1988 & 30 \\
\hline & 1992 & 34 \\
\hline & 1995 & 38 \\
\hline & 2005 & 35 \\
\hline & 2010 & 47 \\
\hline \multirow[t]{5}{*}{ Lakehead } & 1991 & 46 \\
\hline & 1996 & 45 \\
\hline & 1999 & 46 \\
\hline & 2005 & 54 \\
\hline & 2010 & 62 \\
\hline \multicolumn{3}{|c|}{ Comprehensive } \\
\hline \multirow[t]{4}{*}{ York } & 1980 & 79 \\
\hline & 1985 & 50 \\
\hline & 1990 & 50 \\
\hline & 2013 & 67 \\
\hline \multirow[t]{8}{*}{ Waterloo } & 1980 & 15 \\
\hline & 1981 & 22 \\
\hline & 1985 & 42 \\
\hline & 1990 & 46 \\
\hline & 1995 & 50 \\
\hline & 1999 & 83 \\
\hline & 2005 & 44 \\
\hline & 2010 & 50 \\
\hline \multicolumn{3}{|c|}{ Medical/Doctoral } \\
\hline \multirow[t]{4}{*}{ Western } & 1998 & 53 \\
\hline & 2000 & 85 \\
\hline & 2004 & 91 \\
\hline & 2009 & 83 \\
\hline \multirow[t]{6}{*}{ Toronto } & 1978 & 62 \\
\hline & 1985 & 93 \\
\hline & 1987 & 98 \\
\hline & 1991 & 98 \\
\hline & 1994 & 97 \\
\hline & 2010 & 46 \\
\hline
\end{tabular}




\section{Method and Analysis}

The main method used in this study was content analysis. Content analysis provides an empirically grounded method that allows researchers to examine textual and visual content and infer meanings based on the data (Krippendorff, 2004). The use of content analysis for university viewbooks is an appropriate method for two reasons: previous studies on viewbooks have produced valuable data and results through content analysis (Hartley \& Morphew, 2008; Hite \& Yearwood, 2001; Saichaie et al., 2012); and "content analysis entails a systematic reading of texts, images, and symbolic matter, not necessarily from an author's or user's perspective" (Krippendorff, 2004, p. 3). Viewbooks contain both textual and visual information that is necessary for content analysis and that provides a context from which one can study and infer meanings based on their communicative purpose.

Operationalization and coding. To test for levels of corporatization, placement was operationalized as the physical location of content in the viewbook. In this research, quartiles were used as measures of placement. As in magazines and newspapers, it is presupposed that the most important information in a viewbook appears closer to the beginning, so the 1st quartile is noted as the most important. I predicted that the information in the 1st quartile would change over time to represent the changing promotional strategies of the university. More corporatization would be exemplified by a decrease in emphasis on academics and an increase in emphasis on the student experience and university-specific advantages. (Initial operationalization also included measures of photos, graphics, and ratio of text to non-text information; however, it was found that this information was too broad in scope and would be better suited for another paper.)

Coding was done using a multiscan approach. Using an open coding style, data were coded according to the sections in each viewbook, grouping like information into similar sections. The initial 36 sections were reduced to 28 by combining similar information (for example, admissions and applying). Each section was then coded using the following criteria: number of pages with content (sometimes including covers), placement in the viewbook (based on quartiles), and number and percentage of total pages. After an initial analysis, data were further grouped into four categories for an overall evaluation: academics (AC), student experience (SE), university-specific advantages (USA), and general information (GI).

\section{Findings}

Though the main purpose of viewbooks is to communicate information about the university to the student-consumer, they present various types of information. Four main categories of aggregate data were deduced, into which all information could be divided; this made coding easier and allowed for generalizable results across institutions.

- Academics (AC) includes anything related to learning or to getting into university, such as program listings; applications and admissions; and fees, scholarships, and finances.

- The student experience (SE) includes anything that relates to what students can do apart from their studies, such as athletics, recreation, student activities, and campus life; student services; and residence and accommodation. 
- University-specific advantages (USA) includes what the university can offer (not specifically to students), such as historical information and facts about the university and local area; professor and faculty profiles; and ad pages selling the university.

- General information (GI) includes basic information about the university and about the viewbook, such as contact information, maps, campus visits, welcome/opening messages, and tables of contents.

Overall, the picture is complex, and though the results show few perfect trends, there are enough common tendencies to support the initial hypothesis. Generally, AC, both collectively and by individual section, decreased in percentage of total pages, while pages devoted to SE, USA, and GI increased. The same trend was also seen in 1st-quartile placement. Although trends were observed across all universities; there were few significant trends common to only one or two of the three university types (primarily undergraduate, comprehensive, and medical/doctoral).

\section{Raw Data}

The raw data show some interesting trends. Generally, there has been an increase in total number of pages per viewbook, though aggregate data in the four categories do not follow this trend consistently per section (in some years, certain sections increase while others decrease). However, aggregate data do show opposing trends in the percentage of total pages for the AC and USA categories, while the SE and GI categories show trends of convergence. Additionally, program listings-the single largest viewbook section (part of the AC category)-have decreased in percentage of pages over time.

The general trend of increasing pages over time is noticeable in Table 1. Viewbooks at Trent, for example, grew over $110 \%$, from 22 pages in 1979 to 47 in 2010. Lakehead, though not introducing as large an increase, still followed the trend, increasing its viewbook size from 46 pages in 1991 to 62 in 2010. York's viewbook was the longest (79 pages) in 1980 but dropped to 50 pages in 1985 and 1990 before increasing to 67 pages in 2013. Waterloo's viewbooks had substantial page increases, from 15 in 1980 to $50-233 \%$ higher-in 2010. Western's and Toronto's stayed fairly consistent, though one interesting exception is Toronto's drop by about 50\% from 97 pages in 1994 to 46 pages in 2010. This change can be seen in a massive decrease in program pages (see Table 3).

Table 2 shows trends in the aggregate category data: number of pages and percentage of overall pages. A decrease in percentage of overall pages for $\mathrm{AC}$ and an increase for pages devoted to USA are visible trends. In AC pages, the Toronto viewbooks decreased the most, from $80 \%$ in 1978 to $52 \%$ in $2010-$ a change of 28 percentage points. USA pages increased over time, with some universities having no USA pages at all until later viewbooks. The biggest change was again in Toronto's viewbooks, which had no pages for USA until 2010, when the percentage was $28 \%$. Similarly, the Waterloo viewbooks had no pages devoted to USA until 1990; the proportion increased to $28 \%$ in 2005 and back to $12 \%$ by 2010 . These results support the hypothesis that the emphasis on academics has waned over time, while more emphasis has been placed on nonacademic informationuniversity-specific advantages, in this case. 
Table 2.

Aggregate Sections: Number of Pages and Percentage of Overall Viewbook Pages

\begin{tabular}{|c|c|c|c|c|c|c|c|c|c|}
\hline \multirow[t]{2}{*}{ University } & \multirow[t]{2}{*}{ Year } & \multicolumn{2}{|c|}{$\mathrm{AC}$} & \multicolumn{2}{|c|}{ SE } & \multicolumn{2}{|c|}{ USA } & \multicolumn{2}{|c|}{ GI } \\
\hline & & $\begin{array}{l}\text { num- } \\
\text { ber of } \\
\text { pages }\end{array}$ & $\begin{array}{c}\% \text { of } \\
\text { total } \\
\text { pages }\end{array}$ & $\begin{array}{l}\text { num- } \\
\text { ber of } \\
\text { pages }\end{array}$ & $\begin{array}{c}\% \text { of } \\
\text { total } \\
\text { pages }\end{array}$ & $\begin{array}{l}\text { num- } \\
\text { ber of } \\
\text { pages }\end{array}$ & $\begin{array}{c}\% \text { of } \\
\text { total } \\
\text { pages }\end{array}$ & $\begin{array}{l}\text { num- } \\
\text { ber of } \\
\text { pages }\end{array}$ & $\begin{array}{c}\% \text { of } \\
\text { total } \\
\text { pages }\end{array}$ \\
\hline \multirow[t]{8}{*}{ Trent } & 1979 & 16 & 73 & 4 & 19 & 1 & 6 & 0 & 2 \\
\hline & 1981 & 12 & 49 & 7 & 29 & 1 & 5 & 4 & 17 \\
\hline & 1986 & 15 & 51 & 8 & 27 & 6 & 20 & 1 & 4 \\
\hline & 1988 & 19 & 63 & 6 & 22 & 4 & 14 & 2 & 8 \\
\hline & 1992 & 19 & 56 & 6 & 18 & 5 & 15 & 6 & 18 \\
\hline & 1995 & 17 & 45 & 12 & 31 & 8 & 21 & 4 & 9 \\
\hline & 2005 & 21 & 60 & 6 & 17 & 5 & 14 & 3 & 9 \\
\hline & 2010 & 26 & 55 & 8 & 17 & 10 & 21 & 3 & 7 \\
\hline \multicolumn{2}{|c|}{$\begin{array}{l}\text { Change over time } \\
\text { (percentage points) }\end{array}$} & & -18 & & -2 & & +15 & & +5 \\
\hline \multirow[t]{5}{*}{ Lakehead } & 1991 & 38 & 83 & 3 & 7 & 2 & 4 & 3 & 7 \\
\hline & 1996 & 36 & 80 & 4 & 9 & 2 & 4 & 3 & 7 \\
\hline & 1999 & 37 & 80 & 4 & 9 & 2 & 4 & 3 & 7 \\
\hline & 2005 & 41 & 76 & 7 & 13 & 1 & 2 & 5 & 9 \\
\hline & 2010 & 45 & 73 & 10 & 16 & 4 & 6 & 4 & 7 \\
\hline \multicolumn{2}{|c|}{$\begin{array}{l}\text { Change over time } \\
\text { (percentage points) }\end{array}$} & & -10 & & +9 & & +2 & & $\mathrm{O}$ \\
\hline \multirow[t]{4}{*}{ York } & 1980 & 64 & 81 & 3 & 4 & 7 & 9 & 5 & 6 \\
\hline & 1985 & 23 & 46 & 10 & 20 & 8 & 16 & 9 & 18 \\
\hline & 1990 & 25 & 50 & 15 & 30 & 9 & 19 & 6 & 12 \\
\hline & 2013 & 52 & 78 & 5 & 7 & 7 & 11 & 3 & 4 \\
\hline \multicolumn{2}{|c|}{$\begin{array}{l}\text { Change over time } \\
\text { (percentage points) }\end{array}$} & & -3 & & +3 & & +2 & & -2 \\
\hline \multirow[t]{8}{*}{ Waterloo } & 1980 & 12 & 80 & 1 & 7 & $\mathrm{O}$ & $\mathrm{O}$ & 2 & 13 \\
\hline & 1981 & 17 & 79 & 3 & 12 & $\mathrm{o}$ & $\mathrm{O}$ & 2 & 9 \\
\hline & 1985 & 32 & 76 & 4 & 10 & o & o & 6 & 14 \\
\hline & 1990 & 34 & 74 & 7 & 15 & 1 & 3 & 6 & 13 \\
\hline & 1995 & 36 & 72 & 7 & 14 & 2 & 3 & 8 & 16 \\
\hline & 1999 & 62 & 75 & 8 & 10 & 6 & 7 & 7 & 8 \\
\hline & 2005 & 22 & 49 & 3 & 6 & 13 & 28 & 7 & 17 \\
\hline & 2010 & 33 & 65 & 8 & 16 & 6 & 12 & 3 & 6 \\
\hline \multicolumn{2}{|c|}{$\begin{array}{l}\text { Change over time } \\
\text { (percentage points) }\end{array}$} & & -15 & & +9 & & +12 & & -7 \\
\hline
\end{tabular}




\begin{tabular}{|c|c|c|c|c|c|c|c|c|c|}
\hline \multirow[t]{4}{*}{ Western } & 1998 & 37 & 70 & 12 & 22 & 2 & 4 & 4 & 8 \\
\hline & 2000 & 64 & 75 & 11 & 13 & 4 & 5 & 4 & 5 \\
\hline & 2004 & 63 & 69 & 13 & 14 & 4 & 4 & 11 & 12 \\
\hline & 2009 & 57 & 69 & 16 & 19 & 5 & 6 & 4 & 5 \\
\hline \multicolumn{2}{|c|}{$\begin{array}{l}\text { Change over time } \\
\text { (percentage points) }\end{array}$} & & -1 & & -3 & & +2 & & -3 \\
\hline \multirow[t]{6}{*}{ Toronto } & 1978 & 49 & 80 & 7 & 11 & o & o & 3 & 5 \\
\hline & 1985 & 83 & 89 & 3 & 4 & o & o & 7 & 8 \\
\hline & 1987 & 88 & 90 & 7 & 7 & $\mathrm{O}$ & o & 3 & 3 \\
\hline & 1991 & 88 & 90 & 7 & 7 & o & o & 3 & 3 \\
\hline & 1994 & 86 & 89 & 7 & 7 & o & o & 4 & 4 \\
\hline & 2010 & 24 & 52 & 6 & 13 & 13 & 28 & 3 & 7 \\
\hline \multicolumn{2}{|c|}{$\begin{array}{l}\text { Change over time } \\
\text { (percentage points) }\end{array}$} & & -28 & & +2 & & +28 & & +2 \\
\hline
\end{tabular}

Note. Figures have been rounded independently.

Results in Table 2 show convergence in the SE and GI categories. In SE, the universities coalesced into a fairly small range by the final viewbooks studied. Viewbooks published between 2009 and 2013 showed the percentage of total pages devoted to SE converged to a range of $13 \%$ to $19 \%$, a difference of only 6 points. York was an outlier, with $7 \%$. Page counts in the GI category also converged. In the 2009-2013 viewbooks, the range was 4\% to $7 \%$, a difference of only 3 points.

The raw data also show that the program section of viewbooks (including undergraduate, graduate, and professional programs, continuing education, transfer programs, and faculties and departments) is the largest single part and has decreased as a proportion of viewbooks over time. Table 3 shows the program section data: number of pages and percentage of overall viewbook pages. In the majority of the university viewbooks, the number of pages devoted to programs did not decline, and actually increased in most cases. For example, Waterloo's program section went from a total of 4 pages in 1979 to 19 in 2010, while Western's went from 26 pages in 1998 to 45 in 2009. Though the number of program pages actually went up, this rise coincided with the increase in the overall number of pages per viewbook (see Table 1). So in the percentage of overall viewbook pages, the data show an opposite trend-the average percentage of program pages actually declines over time. The viewbooks for Trent, York, and Toronto devoted over $64 \%$ of pages to program descriptions in 1978, 1979, and 1980; the proportion dropped to between $36 \%$ and $50 \%$ in 2010, 2011, and 2013, a reduction of at least 14 percentage points. The biggest drop was in Toronto's viewbooks, where the program section shrank from $73 \%$ in 1978 to $39 \%$ in 2010, a reduction of 34 points. 
Table 3.

Program Section: Number of Pages and Percentage of Overall Viewbook Pages

\begin{tabular}{|c|c|c|c|}
\hline \multirow[t]{2}{*}{ University } & \multirow[t]{2}{*}{ Year } & \multicolumn{2}{|c|}{ Program Section } \\
\hline & & $\begin{array}{c}\text { number of } \\
\text { pages }\end{array}$ & $\begin{array}{c}\% \text { of total } \\
\text { pages }\end{array}$ \\
\hline \multirow[t]{8}{*}{ Trent } & 1979 & 14 & 64 \\
\hline & 1981 & 8 & 33 \\
\hline & 1986 & 9 & 30 \\
\hline & 1988 & 12 & 40 \\
\hline & 1992 & 10 & 29 \\
\hline & 1995 & 11 & 29 \\
\hline & 2005 & 11 & 31 \\
\hline & 2010 & 17 & 36 \\
\hline Change over time (percentage points) & & & -28 \\
\hline \multirow[t]{5}{*}{ Lakehead } & 1991 & 33 & 72 \\
\hline & 1996 & 31 & 69 \\
\hline & 1999 & 32 & 70 \\
\hline & 2005 & 35 & 65 \\
\hline & 2010 & 34 & 54 \\
\hline Change over time (percentage points) & & & -18 \\
\hline \multirow[t]{4}{*}{ York } & 1980 & 56 & 71 \\
\hline & 1985 & 16 & 32 \\
\hline & 1990 & 16 & 32 \\
\hline & 2013 & 34 & 50 \\
\hline Change over time (percentage points) & & & -21 \\
\hline \multirow[t]{8}{*}{ Waterloo } & 1980 & 4 & 27 \\
\hline & 1981 & 7 & 32 \\
\hline & 1985 & 15 & 36 \\
\hline & 1990 & 16 & 35 \\
\hline & 1995 & 16 & 32 \\
\hline & 1999 & 43 & 52 \\
\hline & 2005 & 14 & 31 \\
\hline & 2010 & 19 & 37 \\
\hline Change over time (percentage points) & & & +10 \\
\hline \multirow[t]{4}{*}{ Western } & 1998 & 26 & 49 \\
\hline & 2000 & 55 & 65 \\
\hline & 2004 & 54 & 59 \\
\hline & 2009 & 45 & 54 \\
\hline Change over time (percentage points) & & & +5 \\
\hline
\end{tabular}




\begin{tabular}{lccc}
\hline Toronto & 1978 & 45 & 73 \\
& 1985 & 38 & 41 \\
& 1987 & 43 & 44 \\
& 1912 & 43 & 44 \\
& 1994 & 43 & 44 \\
& 2010 & 18 & 39 \\
Change over time (percentage points) & & & -34 \\
\hline
\end{tabular}

Note. Figures have been rounded independently.

\section{Placement}

Placement of information in the viewbooks was examined two ways: overall by section and first quartile by aggregate categories (AC, SE, USA, and GI). I coded the viewbooks into quartiles by dividing the total number of pages with content by 4 . The page totals of the viewbooks tended not to come in exact multiples of 4 , so the lowest whole number after dividing by 4 was used to mark off the 1st quartile. The remainder of the pages were apportioned to the other quartiles according to this formula: if 1 page remained, it was added to the 4th quartile; if 2 pages remained, they went to the 2nd and 3rd quartiles; and if 3 pages remained, they went to the 2 nd, 3 rd, and 4 th quartiles. For example, a book of 45 pages was divided into 11 pages per quartile, with the 4th quartile having 12 pages; a book of 30 pages was divided into 7 pages per quartile, with the 2nd and 3rd quartiles having 8 pages; and a book of 47 pages was divided into 11 pages per quartile, with the 2nd, 3rd, and 4th quartiles having 12 pages. (The formula applies to the raw data only: 1st-quartile analysis used the actual divided number, so a 30-page book was treated as having 7.5 pages per quartile.)

The placement data show trends in both the individual sections and aggregate scores in the 1st quartile. Again, the results show a change in the position of AC at both the individual level and aggregate level. This change was inversely proportional to trends for some of AC's individual sections such as student services; athletics, recreation, student activities, and campus life; and residence. The same relationships are evident in 1st-quartile aggregate scores of SE and USA.

Overall section placement. Individual sections, because there were only four possible placements, did not show as much variation as was hoped, though there were some trends. Some placements moved from the 3rd and 4th quartiles to the 1st, and there were also convergent points (though these mostly coincided with the moves).

The program section was too large to exhibit any trends; however, in applications and admissions-another AC section-a shift from the front towards the back is seen. There was a shift from the 1st and 2nd quartiles to the 4th quartile for most viewbooks, though York and Western placed this section consistently in the 4th quartile, suggesting more of a convergence.

Some individual sections that showed a trend moving from the last two quartiles in the earlier viewbooks to the first two quartiles in the latest viewbooks were: student services; athletics, recreation, student activities, and campus life; and residence and accommoda- 
tion. The change occurred fairly abruptly for most universities; but the Trent viewbook had a more prolonged transition for the athletics, recreation, student activities, and campus life section and the residence and accommodation sections.

Some other individual section placements were of note. International opportunities, when present, were in the 1st quartile of the most recent viewbooks. Toronto was the only university with no specific mention of international opportunities. Similarly, when present, both 'about the university' and the 'university system/approach to teaching' sections were in the 1st quartile over all viewbook years.

1st-quartile placement. Placement of aggregate scores in the 1st quartile shows trends similar to the trends for the raw data, with the emphasis on $\mathrm{AC}$ waning while the emphasis on SE, USA, and GI generally increasing.

In the aggregate scores for 1st-quartile placement, a trend of AC decreasing over time is seen. Figure 1 shows the percentage of pages in the 1st quartile for AC. The chart shows a decline across all universities' viewbooks, with Toronto's and Waterloo's having the most significant drops. In Toronto's viewbooks, the proportion of pages devoted to academics decreased from almost $77 \%$ in 1978 to o in 2010, while the Waterloo viewbook declined in proportion from $100 \%$ in 1980 to $32 \%$ in 2010: changes of 77 and 68 percentage points respectively.
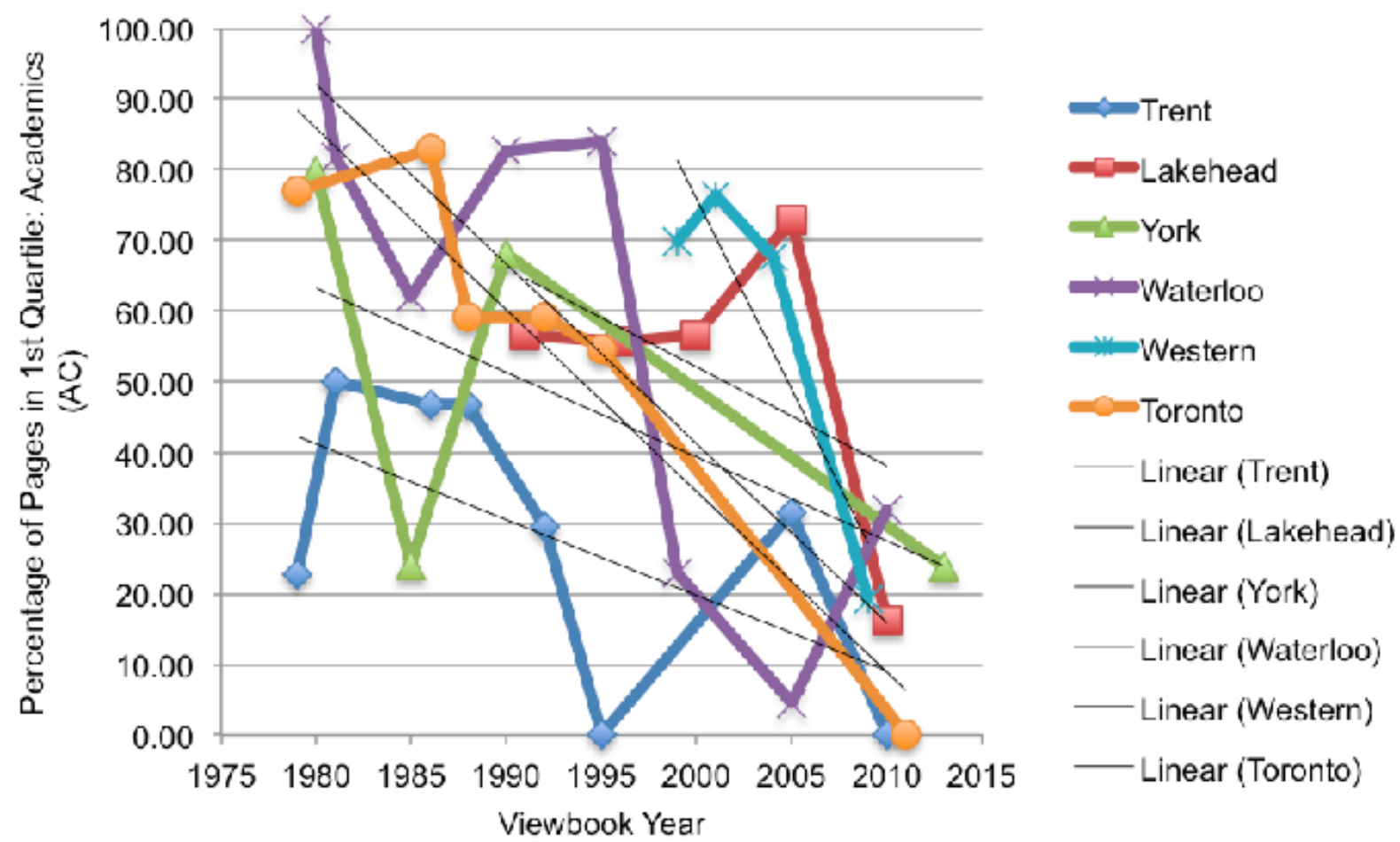

Figure 1. Percentage of Pages in 1st Quartile: Academics (AC) 


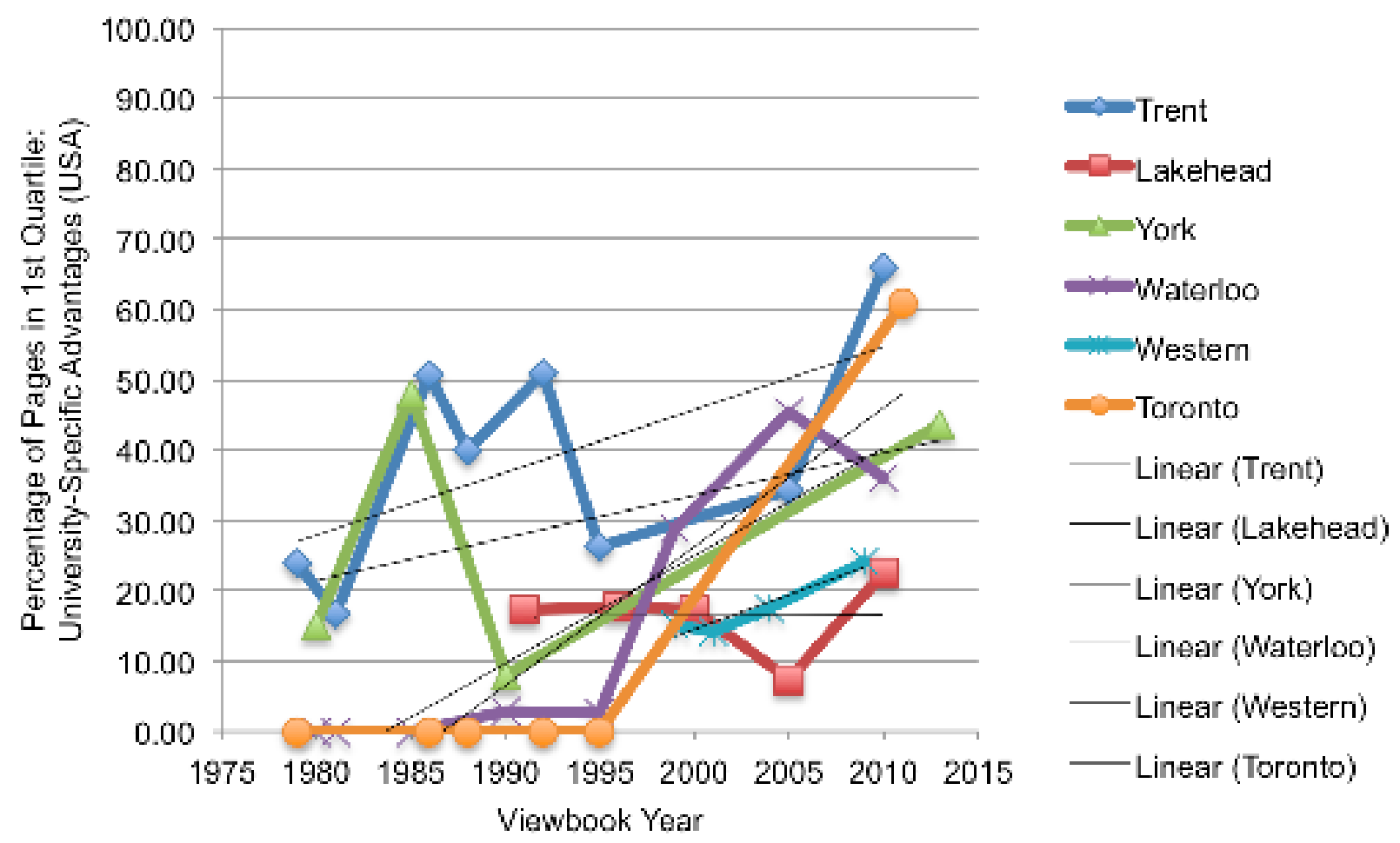

Figure 2. Percentage of Pages in 1st Quartile: University-Specific Advantages (USA)

While the percentage of $\mathrm{AC}$ pages in the 1st quartile has decreased, the percentage in SE and USA pages has increased, though the trend for SE is much more complex. Figure 2 shows the percentage of pages in the 1st quartile for USA. It shows an upward trend of percentage of pages devoted to USA, with the Toronto and Waterloo viewbooks again having the most significant changes. Toronto's increased from no pages devoted to USA in 1994 to nearly $61 \%$ in 2010, while Waterloo's increased from no pages in 1985 to $36 \%$ in 2010 : changes of 61 and 36 percentage points respectively. It must be noted that only one of Toronto's viewbooks, the 2010 edition, had USA pages, though this should not have an impact on overall data. These increases coincide, though not perfectly, with the decline in AC pages.

The SE pages' data were more complex, which flattened out the trends. Though, the trends were flattened, the tendency was still an increase in percentage of pages devoted to SE over time. The biggest shift can be seen with Lakehead's viewbook, which devoted roughly $9 \%$ of 1st-quartile pages to SE in 1991 and approximately 55\% in 2010: a change of 46 percentage points.

GI pages were fairly steady across viewbooks, with no trends noted.

\section{Discussion}

The findings support the initial hypothesis that viewbooks have changed over time to reflect more corporatized and commodified universities, though the timing of such changes is complex and uneven. Overall, the placement of content in the majority of university viewbooks has evolved from 1980 to 2010. Though the data show that a change has occurred, they do not definitively identify when change was initiated across all univer- 
sities. Further complicating the results is the fact that different aspects of the viewbooks changed at different times, with some changes being gradual while others were sudden. The results show that the change in viewbook treatment of academics, the student experience, and university-specific advantages has occurred, for the most part, since 1995, suggesting that universities might have used funding cuts as a point of departure for increased corporatization, though this is not certain.

\section{From Academics to the University Experience}

In response to the first research question-"Have viewbooks changed over time in a manner that reflects a shift toward university corporatization?"-the findings suggest that there has been a trend towards more corporatization in viewbooks. Through all measures of placement of content of individual sections and the four aggregate categories, the results point to a decrease in the emphasis on $\mathrm{AC}$ and an increased emphasis on the university experience (SE and USA). The overall data show that the percentage of pages devoted to $\mathrm{AC}$ has decreased while the pages describing USA have increased. Also, the placement of AC pages has moved back from the 1st and 2nd quartiles, so that pages devoted to SE and USA may move up from the 4th quartile. The 1st-quartile percentages further emphasize the push away from academics towards the experience of university. As with the overall data, the quartile analysis shows a decrease in AC and an increase in SE and USA. Given that the universities' goal is education (though this is a contentious point), this push further emphasizes the corporatization of universities.

Also of note is the appearance of advertising-style pages-pages meant to sell the university by having many facts, 'chunks' of information from all sections, and specific university promises and guarantees; in this study, these pages were counted in the USA category. The trend started in York's 1980 viewbook but disappeared after 1985, with contemporary advertising-style pages reappearing in its 2013 viewbook. Advertising-style pages appeared in most of the other universities' viewbooks after 2001, with Trent's being the only viewbook without advertising-style pages. This timing is significant, though it may demonstrate a lag in response to the funding cuts. Also significant is the fact that these pages appeared in the 1st quartile of the viewbooks, further confirming the universities' shift in emphasis from academics towards university-specific advantages.

Additionally, the change in focus towards a student experience orientation shows how the university has moved away from its core function of education towards the experience as its main selling point. Because the student experience and university-specific advantages do not necessarily equate to academics, it is safe to say that the university has moved toward corporatizing the experience that it can provide, rather than the education the student can receive.

For the second research question-"If there is temporal change, is it gradual or sudden?"-the findings are less clear. With both individual sections and aggregate scores, the change is either sudden or gradual, depending on the university. Noting, specifically, the increase in SE pages combined with the increase in USA pages, we can see that the change away from academics and towards a more corporatized view has changed both over time and suddenly. This suggests that particular aspects of the university experience gained prevalence at different times, though corporatization occurred across all experiences. Upon further examination, the change from specific SE sections and the overall SE score 
show that the change is university specific, though most of the changes were sudden and most occurred in or after 1995 (Toronto's viewbook spiked in 1987). There are similarities with specific USA sections, though they were more consistent across the Trent, Lakehead, and Western publications, with the other three universities spiking significantly in or after 1999. This would suggest that SE was being pushed earlier and closer to the suggested 1995 funding cuts, whereas USA was more heavily pushed later and closer to 2000.

\section{Conclusion}

As the findings and discussion of this project have indicated, there has been a significant change in Ontario's university viewbooks from 1980 to 2010. The emphasis on what is important has changed in the viewbooks. With an increased emphasis on the student experience and university-specific advantages, and a decreased emphasis on academics, there is definitely a change in marketing approaches employed by universities. Though we cannot use these data to generalize to all universities in Ontario or Canada, the trends seem to indicate that more current university viewbooks are selling a more corporatized version of the university: one that sells the experience rather than the educational outcomes. Also, though there has been a change in the viewbooks, the timing of those changes is somewhat murky, and as such, we cannot definitively say that it was the 1996 funding cuts that increased corporatization.

What can be said, though, is that universities' marketing of themselves has become more corporatized over time, and this is not necessarily a good thing. If a university's marketing seems to be changing focus away from academics towards the student experience and university-specific advantages, chances are that money is being spent to emphasize those aspects as well. Future studies may want to look longitudinally at the allocation of funding in universities as a comparison with the change in the viewbooks. Additionally, there is an opportunity to see how funding changes over time (rather than at one point in time) affect viewbook content. Other future studies, though not directly related to the financial aspect, could look at the Internet's impact on viewbook content changes and could examine longitudinally universities' website recruitment strategies and content changes.

When more and more people are attending universities, it seems that the emphasis on having a good time, rather than on learning, clouds the expected outcomes of the university. This is problematic because when more and more student- and parent-consumers view education as a commodity, they seek to get a better return on investment; however, if the corporate university does not make money from education and instead garners more funding by selling the university experience, then the goals and the outcomes are at odds. Universities have to move away from corporatization and back towards academics if they are to survive, because in the long run further emphasis and expansion of corporate ideals will end in education being a commodity that few can afford. Education will no longer be the great equalizer it has been purported to be.

\section{Acknowledgements}

I would like to thank Professor Tracey Adams for helpful insights and assistance in refining this article and throughout the research process, and Professor Wolfgang Lehmann for his insights throughout the revision process. 


\section{References}

Apple, M. W. (2007). Whose markets, whose knowledge? In A. R. Sadovnik (Ed.), Sociology of education: A critical reader (pp. 177-193). New York, NY: Routledge.

Breland, H., Maxey, J., Gernand, R., Cumming, T., \& Trapani, C. (200o). Trends in college admission 2000: A report of a national survey of undergraduate admission policies, practices, and procedures. Retrieved from http://www.semworks.net/aboutus/resources/docs/trends_in_college_admission.pdf

Clark, I. D., Moran, G., Skolnik, M. L., \& Trick, D. (2009). Academic transformation: The forces reshaping higher education in Ontario. Kingston, ON: McGill-Queen's University Press.

Clark, I. D., Trick, D., \& Van Loon, R. (2011). Academic reform: Policy options for improving the quality and cost-effectiveness of undergraduate education in Ontario. Kingston, ON: McGill-Queen's University Press.

Coates, K. S., \& Morrison, B. (2011). Campus confidential: 100 startling things you don't know about Canadian universities. Toronto, ON: Lorimer.

Commission on the Future Development of the Universities in Ontario. (1984). Ontario universities: Options and futures. Toronto, ON: Author.

Côté, J. E., \& Allahar, A. L. (2011). Lowering higher education: The rise of corporate universities and the fall of liberal education. Toronto, ON: University of Toronto Press.

Davidson-Harden, A., \& Majhanovich, S. (2004). Privatisation of education in Canada: A survey of trends. International Review of Education, 5O(3/4), 263-287.

Durgin, K. L. (1998). Is it worth it? Viewbooks as communication between colleges and prospective students. Journal of College Admission, 159, 22-29.

European Students' Union.(2005). 2005 Policy Paper “Commodification of Education.” Retrieved from http://www.esu-online.org/news/article/6064/90/

Giroux, H. A., \& Searls Giroux, S. (2004). Take back higher education: Race, youth, and the crisis of democracy in the post-civil rights era. New York, NY: Palgrave Macmillan.

Hacker, A., \& Dreifus, C. (2010). Higher education?: How colleges are wasting our money and failing our kids-and what we can do about it. New York, NY: Times Books.

Hartley, M., \& Morphew, C. C. (2008). What's being sold and to what end?: A content analysis of college viewbooks. Journal of Higher Education, 79(6), 671-691. doi:10.1353/ jhe.0.0025

Häyrinen-Alestalo, M., \& Peltola, U. (2006). The problem of a market-oriented university. Higher Education, 52(2), 251-281. doi:10.1007/s

Hite, R. E., \& Yearwood, A. (2001). A content analysis of college and university viewbooks (brochures). College and University, 76(3), 17-21.

Kaye, T., Bickel, R. D., \& Birtwistle, T. (2006). Criticizing the image of the student as consumer: Examining legal trends and administrative responses in the US and UK. Education and the Law, 18(2-3), 85-129. 
Kirp, D. L. (2004). Shakespeare, Einstein, and the bottom line: The marketing of higher education (2nd ed.). Cambridge, MA: Harvard University Press.

Klein, N. (2000). No logo: Taking aim at the brand bullies. Toronto, ON: Vintage Canada.

Krippendorff, K. (2004). Content analysis: An introduction to its methodology (2nd ed.). Thousand Oaks, CA: Sage Publications.

Lucas, J. (1998, September 23). U. of C. marketers ditch tradition in new viewbook. University of Chicago Weekly News. Retrieved from http://www.bayarea.net/ kins/ AboutMe/Hutchins_items/UofC_marketers_ditch_trad.html

Maclean's. (2013). Rankings - Maclean's on campus. Retrieved March 6, 2013, from http://oncampus.macleans.ca/education/rankings/

Newfield, C. (2008). Unmaking the public university: The forty-year assault on the middle class. Cambridge, MA: Harvard University Press.

Ontario Ministry of Colleges and Universities. (1981). Report of the Committee on the Future Role of Universities in Ontario. Toronto, ON: Author.

Saichaie, K., Hevel, M., \& Morphew, C. C. (2012, November). A content analysis of 40 years of college viewbooks. Paper presented at the annual conference of the Association for the Study of Higher Education, Las Vegas, NV.

Slaughter, S., \& Rhoades, G. (2009). Academic capitalism and the new economy: Markets, state, and higher education. Baltimore, MD: Johns Hopkins University Press.

Supiano, B. (2012, February 19). For courting students, glossy viewbooks lose luster. Chronicle of Higher Education. Retrieved from http://chronicle.com/article/articlecontent/130851/

Taylor, M. C. (2010). Crisis on campus: A bold plan for reforming our colleges and universities. Toronto, ON: Random House.

Tuchman, G. (2011). Wannabe U: Inside the corporate university. Chicago, IL: University of Chicago Press.

Turk, J. (2000). The corporate campus: Commercialization and the dangers to Canada's colleges and universities. Toronto, ON: Lorimer.

Weinstock, J. (2010). Left to their own devices. THE Journal. Retrieved from http:// thejournal.com/articles/2010/01/o8/left-to-their-own-devices.aspx

Westheimer, J. (2010). Higher education or education for hire? Corporatization and the threat to democratic thinking. Academic Matters. Retrieved from http://www. academicmatters.ca/2010/o4/higher-education-or-education-for-hire-corporatizationand-the-threat-to-democratic-thinking/

\section{Contact Information}

Cliff Davidson

Department of Sociology

University of Western Ontario

cdavid44@uwo.ca 
Cliff Davidson is pursing his $\mathrm{PhD}$ in sociology at the University of Western Ontario. His studies focus on root causes of problems in the education system, specifically higher education. His current research focuses on student typologies. Cliff also enjoys photography and is the executive director of the Toronto Urban Photography Festival, which seeks to deconstruct and reconstruct new formulations of contemporary urban landscapes through the practice of photography. 